\title{
Effects of STZ-Induced Diabetes on the Relative Weights of Kidney, Liver and Pancreas in Albino Rats: A Comparative Study
}

\author{
Efectos de la Diabetes Inducida por STZ en los Pesos Relativos de Riñón, Hígado y Páncreas \\ en Ratas Albinas: un Estudio Comparativo
}

"Muhammad Zafar \& **Syed Naeem-ul-Hassan Naqvi

ZAFAR, M. \& NAEEM-UL-HASSAN NAQVI, S. Effects of STZ-Induced diabetes on the relative weights of kidney, liver and pancreas in albino rats: a comparative study. Int. J. Morphol., 28(1):135-142, 2010.

SUMMARY: We studied the effects of streptozotocin (STZ)-induced diabetes on the body weights of animals and the relative weights of kidney, liver and pancreas in albino rats. The aim of the study was to find an association between the reduction in the body weights of diabetic animals and the relative weights of kidney, liver and pancreas in proportion to the body weight of animals in albino rats. This study was performed in the Department of Anatomy and Institute of Pharmaceutical Sciences, Baqai Medical University, Karachi and Pathology department of College of Physicians \& Surgeons (CPSP) Pakistan in 2007-08. Diabetes was induced by a single dose of STZ (45 mg/kg, b.w.) given intraperitoneally in sodium citrate buffer at $\mathrm{pH} 4.5$. Eighty albino rats were divided into five groups: control (A) and STZ treated (B, C, D, and E) which were sacrificed 2, 4, 6 and 8 weeks post treatment respectively. All the animals were weighed prior to the administration of streptozotocin and at sacrificial time. Kidney, liver and pancreas were removed, dried and weighed on Sartorius balance. The body weights of animals in different groups changed at variable time intervals. The Kidney weight was significantly increased, liver weight was slightly increased while the weight of pancreas was unaffected when compared with the weight of diabetic animals. It seems that the STZ-induced diabetes causes a significant reduction in the body weight of diabetic animals while the relative weights of kidney and liver were increased and the weight of pancreas was unaffected.

KEY WORDS: STZ-diabetes; Body weights; Weight of kidney; Liver; Pancreas; Rats.

\section{INTRODUCTION}

STZ is a naturally occurring nitrosourea with molecular weight of 265 and empirical formula of $\mathrm{C}_{14} \mathrm{H}_{27}$ $\mathrm{N}_{5} \mathrm{O}_{12}$ (Dorr \& Fritz, 1980). It is widely used to induce insulin-dependent diabetes mellitus in experimental animals because of its toxic effects on islet beta cells (Punithavathi et al., 2008; Fadillioglu et al., 2008). The diabetogenic action of STZ is the direct result of irreversible damage to the pancreatic beta cells resulting in degranulation and loss of capacity to secrete insulin (Gu et al., 1997). The effects of STZ on different organs have been extensively studied. STZ has various biological actions, including the production of acute and chronic cellular injury, carcinogenesis, teratogenesis and mutagenesis (Magee \& Swann, 1969). STZ is a nitrosourea compound which generally shares similar fate of disposition with other nitrosoureas and is a drug of choice in islet cell carcinoma and malignant carcinoid tumors. It is diabetogenic, hepatotoxic, nephrotoxic and also causes gastric ulceration (Piyachaturawat et al., 1988; Piyachaturawat et al., 1991). STZ given intravenously or intraperitoneally to laboratory mice in multiple sub-diabetogenic doses, induces pronounced pancreatic insulitis with eventual destruction of insulin-secreting beta cells and diabetes mellitus. In an experimental study in rats, streptozotocin given intraperitoneally in a dose of $45 \mathrm{mg} / \mathrm{kg}$ body weight of animals, effectively produced hyperglycaemia (Zafar et al., 2009a, b). In another study in rats, STZ injected in a dose of $65 \mathrm{mg} / \mathrm{kg}$ body weight effectively produced hyperglycemia and gastric mucosal ulcerations (Piyachaturawat et al., 1988; Piyachaturawat $e t$ al., 1991). The incidence and severity of lesions produced by STZ in pancreas, liver, kidney and GIT, progressively increased with time from one to six weeks post treatment (Piyachaturawat et al., 1988).

\footnotetext{
* Department of Anatomy, Baqai Medical University, Karachi, Pakistan.

${ }^{* *}$ Faculty of Medicine, King Fahad Medical City, Riyadh.
} 


\section{MATERIAL AND METHOD}

This study was performed in the Department of Anatomy and Institute of Pharmaceutical Sciences, Baqai Medical University, Karachi and Pathology department of College of Physicians \& Surgeons (CPSP) Pakistan in 200708. STZ was obtained in powder form from Sigma Chemical Company, St.Louis, USA.

Immediately before use, STZ was dissolved in 10 $\mathrm{mM}$ sodium citrate buffer, $\mathrm{pH} 4-4.5$, made isotonic by the addition of an appropriate volume of $0.25 \mathrm{M} \mathrm{NaCl}$ (Bennett \& Pegg, 1981). After taking approval from the ethical committee, a total of 80 adult male albino rats (body weight 100-200 gm) of Jinnah Postgraduate Medical College (J.P.M.C) strain, originally obtained from Charles River Breeding Laboratories Brooklyn, Massachussets, USA were used in the study. All rats were housed in metabolic cages on a 12-h light/dark cycle at a temperature of $22-24^{\circ} \mathrm{C}$ (Petlevski et al., 2006). The animals were divided into five groups; A, B, C, D, and E. There were 40 animals in group 'A' while groups B, C, D, and E each comprising of 10 animals. The group 'A' was control and groups B, C, D, and $\mathrm{E}$ were treated with STZ. After an overnight fast, the animals of groups B, C, D, and E were injected with a single dose of STZ ( $45 \mathrm{mg} / \mathrm{kg}$, b.w.) intraperitoneally in sodium citrate buffer at pH 4.5 (Zafar et al., 2009a, 2009b; Ramesh \& Pugalendi, 2006). After the administration of STZ, the animals were given $1 \%$ sucrose solution to prevent hypoglycemia. Plasma glucose was estimated before the administration of STZ, after 24 hours and at the end of 2nd, 4th, 8th and 12th weeks by taking blood samples from the tail vein (Petlevski et al.). Animals in group 'A' (control) were administered sodium citrate buffer $\mathrm{pH} 4.5$ in a dose of $0.2 \mathrm{ml} / 100$ grams body weight, intraperitoneally. After an overnight fast, the animals of group B, C, D and E were sacrificed at the end of 2nd, 4th, 8th and 12th weeks respectively while ten animals from the control group were sacrificed at the end of 2nd, 4th, 8th and 12th weeks respectively (Zafar et al., 2009a, 2009b; Ren et al., 2009). The animals in all groups were weighed prior to the administration of STZ and before their sacrifice at the end of 2nd, 4th, 8th and 12th weeks respectively. At the time of sacrifice, the kidney, liver and pancreas of the animals of group 'A' and animals of group ' $E$ ' were identified, removed, dried by tissue papers and weighed on Sartorius balance prior to fixation to determine the change in the weight of organs with respect to their body weights and was statistically analyzed.

Statistical analysis of the data. Data are shown as means \pm S.E.M. The statistical significance of differences of various quantitative changes between streptozotocin treated and control rats was evaluated by student ?t' test (Swinscow, 1981). The difference was regarded as statistically highly significant if the ?P' value was less than 0.001 and 0.01 . The difference was regarded as statistically significant if the ?P' value was less than 0.02 and 0.05 . And, the difference was regarded as statistically non-significant if the ?P' value was greater than 0.1 and 0.5 . The statistical significance of the changes in plasma glucose levels and weight of control and streptozotocin treated animals were evaluated by paired ?t' test (Swinscow). The differences between the final readings and the initial readings in each group were taken and their mean was taken. ?t' value was calculated by the formula: $\mathrm{t}=$ Mean / S.E. (where S.E. is the standard error).

The difference was regarded as statistically highly significant if the ?P' value was less than 0.001 and 0.01 . The difference was regarded as statistically significant if the ?P' value was less than 0.02 and 0.05 . And, the difference was regarded as statistically non-significant if the ?P' value was greater than 0.1 and 0.5 . The ?P' value was found by means of ?t' distribution table, with the help of which ?P' value was read against the degree of freedom (d.f.) which in turn was determined by the formula: d.f. $=\mathrm{n}-1$, where ?n' is the number of observations in a group.

The statistical significance of the changes in weight of organs in proportion to the body weight of animals was done as follows:

Mean weight of the animals in group-A and group-E were taken. Similarly, mean weights of kidney, liver and pancreas of the animals in groups $\mathrm{A}$ and $\mathrm{E}$ were taken. The mean weights of the organs were converted to weight in $\mathrm{gm} / \mathrm{kg}$ body weight of animals. The ratios of weight in $\mathrm{gm} /$ $\mathrm{kg}$ body weight were compared between groups $\mathrm{A}$ and $\mathrm{E}$.

\section{RESULTS}

During the experimental study, the animals from normal control group and STZ-treated groups remained alive. The animals in group-A appeared healthy, active and gained body weight. The animals in groups B, C, D and E appeared ill looking, showed polydipsia with their plasma glucose level increased and also showed loss of body weight.

Comparison of plasma glucose levels between groups A, B, C, D and E. Statistically, no significant difference was observed in the initial values of plasma glucose levels when groups A, B, C, D and E were compared as shown in Table I. A highly significant decrease $(\mathrm{P}<0.001)$ was observed in 
the final values of the plasma glucose levels when group-A was compared with groups-B, C, D and E and a significant difference $((\mathrm{P}<0.01)$ was observed in the final values of plasma glucose levels when group-B was compared with group-D as shown in Table I. Statistically, no significant difference was observed in the final values of plasma glucose levels between other groups as shown in Table I.

The mean plasma glucose levels of all rats in different groups at variable time intervals were also analyzed with Fstatistics. The F-calculated for treatment levels (i.e. before and after STZ treatment) was $\mathrm{F}=97.78$ with $\mathrm{P}=0.0001$ and for blocks (i.e. groups A, B, C, D and E) was F $=3.56$ with $\mathrm{P}=0.009$. So it may be concluded the plasma glucose levels were significantly higher after administration of STZ and plasma glucose levels were significantly increased in groups increasing with time.

Comparison of body weights between groups A, B, C, D and E. A significant difference $(\mathrm{P}<0.05)$ was observed in the initial values of the body weights when group-B was compared with group-C as shown in Table II. Statistically, no significant difference was observed in the initial values of the body weights between other groups as shown in Table II. A highly significant decrease $(\mathrm{P}<0.001)$ was observed in the final values of the body weights when groups-B, C, D and $\mathrm{E}$ were compared with group-A as shown in Table II. Statistically, no significant difference was observed in the final values of the body weights between other groups as shown in Table II.

The mean body weights of all rats in different groups at variable time intervals were also analyzed with F-statistics. The F-calculated for treatment levels (i.e. before and after STZ treatment) was $\mathrm{F}=0.38$ with $\mathrm{P}=$ 0.537 and for blocks (i.e. groups A, B, C, D and E) was F $=18.94$ with $\mathrm{P}=0.001$. So it may be concluded the body weight was significantly different before and after STZ treatment and body weight was significantly different in groups A-E.

Table I. Statistical analysis of plasma glucose levels $(\mathrm{mg} / 100 \mathrm{ml})$ between different groups at variable time intervals $(X \pm$ S.E.M.).

\begin{tabular}{lcc}
\hline S tatistical comparison & Comparison between initial values & Comparison between final values \\
\hline Group A vs. B & $7.5 \pm 4.08$ (N.S.) & $152.9 \pm 26.80^{* * * *}$ \\
Group A vs. C & $0.7 \pm 3.73$ (N.S.) & $268.1 \pm 52.99 * * * *$ \\
Group A vs. D & $0.94 \pm 3.18$ (N.S.) & $322.2 \pm 45.65 * * * *$ \\
Group A vs. E & $0.0 \pm 3.01$ (N.S.) & $244.2 \pm 43.00^{* * * *}$ \\
Group B vs. C & $6.8 \pm 4.77$ (N.S.) & $115.2 \pm 59.22$ (N.S.) \\
Group B vs. D & $3.6 \pm 4.32$ (N.S.) & $169.0 \pm 52.78^{* *}$ \\
Group B vs. E & $7.5 \pm 4.32$ (N.S.) & $91.3 \pm 50.47$ (N.S.) \\
Group C vs. D & $3.2 \pm 4.02$ (N.S.) & $54.1 \pm 69.82$ (N.S.) \\
Group C vs. E & $0.7 \pm 3.89$ (N.S.) & $23.9 \pm 68.10$ (N.S.) \\
Group D vs. E & $3.9 \pm 3.36$ (N.S.) & $78.00 \pm 62.58$ (N.S.) \\
\hline
\end{tabular}

N.S.=Non-Significant, $* *=p<0.02, * * * *=p<0.001$.

Table II. Statistical analysis of body weights (Grams) between different groups at variable time intervals (X \pm S.E.M.).

\begin{tabular}{lcc}
\hline Statistical comparison & Comparison between initial values & Comparison between final values \\
\hline Group A vs. B & $3.9 \pm 6.52$ (N.S.) & $87.0 \pm 8.68^{* * * *}$ \\
Group A vs. C & $13.1 \pm 6.74$ (N.S.) & $103.8 \pm 10.73^{* * * * *}$ \\
Group A vs. D & $13.9 \pm 9.22$ (N.S.) & $100.9 \pm 11.08^{* * * * *}$ \\
Group A vs. E & $1.0 \pm 6.22$ (N.S.) & $95.3 \pm 12.8^{* * * *}$ \\
Group B vs. C & $17.00 \pm 6.48^{*}$ & $16.5 \pm 10.35$ (N.S.) \\
Group B vs. D & $17.8 \pm 9.03$ (N.S.) & $13.6 \pm 10.6$ (N.S.) \\
Group B vs. E & $4.9 \pm 5.95$ (N.S.) & $8.0 \pm 12.51$ (N.S.) \\
Group C vs. D & $0.8 \pm 9.19$ (N.S.) & $2.9 \pm 12.41$ (N.S.) \\
Group C vs. E & $12.1 \pm 6.18$ (N.S.) & $8.5 \pm 14.00$ (N.S.) \\
Group D vs. E & $12.9 \pm 8.82$ (N.S.) & $5.6 \pm 14.27$ (N.S.)
\end{tabular}

N.S.=Non-Significant, $* *=\mathrm{p}<0.02, * * * *=\mathrm{p}<0.001$. 


\section{Observations on the weights of kidneys, liver and} pancreas in group-A and group-B.

The mean values of the weight of kidney were 0.563 \pm 0.02 and $0.49 \pm 0.016$ grams in groups-A and E respectively as shown in Table III. Kidney weight was significantly increased in diabetic rats of group-E (3.76 gm/ $/ \mathrm{kg}$ b.w. v/s $2.5 \mathrm{gm} / \mathrm{kg}$ b.w.) when compared with non-diabetic rats of group-A as shown in Table IV.

The mean values of the weight of liver were $5.243 \pm$ 0.39 and $3.493 \pm 0.067$ grams in groups- $A$ and E respectively as shown in Table III. Liver weight was slightly increased in diabetic rats of group-E ( $26.80 \mathrm{gm} / \mathrm{kg}$ b.w. v/s $23.24 \mathrm{gm} /$ $\mathrm{kg}$ b.w.) when compared with non-diabetic rats of group-A as shown in Table IV.

The mean values of the weight of pancreas were 0.253 \pm 0.01 and $0.145 \pm 0.04$ grams in groups-A and E respectively as shown in Table III. Pancreas weight was unaffected in diabetic rats of group-E $(1.12 \mathrm{gm} / \mathrm{kg}$ b.w. v/s $1.11 \mathrm{gm} / \mathrm{kg}$ b.w.) when compared with non-diabetic rats of group-A as shown in Table IV.

Table III. Showing mean \pm S.E.M. of weights of animals in groups A and E and weights of kidneys, liver and pancreas at sacrificial time

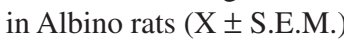

\begin{tabular}{|c|c|c|c|c|}
\hline Groups & $\begin{array}{c}\text { Mean weight of } \\
\text { animals at sacrificial } \\
\text { time (Grams) }\end{array}$ & $\begin{array}{c}\text { Mean weight of } \\
\text { Kidneys } \\
\text { (Grams) }\end{array}$ & $\begin{array}{c}\text { Mean weight of } \\
\text { Liver } \\
\text { (Grams) }\end{array}$ & $\begin{array}{c}\text { Mean weight of } \\
\text { Pancreas } \\
\text { (Grams) }\end{array}$ \\
\hline Group-A (Normal control) & $225.6 \pm 6.48$ & $0.563 \pm 0.02$ & $5.243 \pm 0.39$ & $0.253 \pm 0.01$ \\
\hline Group-E (STZ-Treated- 12 & $130.3 \pm 11.09$ & $0.49 \pm 0.016$ & $3.493 \pm 0.067$ & $0.145 \pm 0.04$ \\
\hline
\end{tabular}

Table IV. Showing comparison between ratios of weight of organ in grams to weight of animal in kilograms in groups A and E of Albino

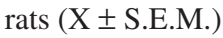

\begin{tabular}{lccc}
\hline Groups & $\begin{array}{c}\text { Weight of kidney in } \\
\text { grams/kg body weight }\end{array}$ & $\begin{array}{c}\text { Weight of liver in } \\
\text { grams/kg body weight }\end{array}$ & $\begin{array}{c}\text { Weight of pancreas in } \\
\text { grams } / \mathbf{k g} \text { body weight }\end{array}$ \\
\hline Group-A (Normal control) & $2.5 \mathrm{gm} / \mathrm{kg}$ & $23.24 \mathrm{gm} / \mathrm{kg}$ & $1.12 \mathrm{gm} / \mathrm{kg}$ \\
Group-E (STZ-Treated- 12 weeks) & $3.76 \mathrm{gm} / \mathrm{kg}$ & $26.80 \mathrm{gm} / \mathrm{kg}$ & $1.11 \mathrm{gm} / \mathrm{kg}$ \\
\hline
\end{tabular}

\section{DISCUSSION}

Studies have shown an association between hyperglycemia and decreased body weight of diabetic animals. The present study was designed to observe the effects of streptozotocin (STZ)-induced diabetes and to find an association between the reduction in the weights of animals and the relative weight of kidney, liver and pancreas in albino rats.

In the present study, streptozotocin was used in a dose of $45 \mathrm{mg} / \mathrm{kg}$ body weight while Mozaffari et al. (1997) used $90 \mathrm{mg} / \mathrm{kg}$ body weight intraperitoneally in rats, Kang et al. (1999) used $70 \mathrm{mg} / \mathrm{kg}$ body weight intravenously in rats and Oscika et al . (2000) used STZ in a dose of $50 \mathrm{mg} / \mathrm{kg}$ body weight intravenously in rats for producing hyperglycaemia. The selection of lower dose was adopted as present strain of rats could not tolerate and survive with the dose used by previous investigators.
Before recording the findings on the kidney, liver and pancreas, the effects of streptozotocin on the behavior of animals, plasma glucose levels and body weights were noted. The observations and results of the present study demonstrated that streptozotocin was effective in producing severe hyperglycaemia in experimental animals (Habibuddin et al., 2008; Lee et al., 2008; Kim, 2006; Heidari et al., 2008).

The animals treated with STZ in groups B, C, D and $E$ appeared ill-looking with loss of their body weights because of injurious effects of STZ which caused alkylation of DNA and produced hyperglycaemia and necrotic lesions. Present observations are in agreement with the findings of Piyachaturawat et al. (1988), Habibuddin et al. and Lee et al. 
In the present study, increase in the weight of kidney (hypertrophy) in proportion to the body weight in STZtreated animals of group-E was noted when compared with group-A animals despite the fact that the mean weight of all the animals in STZ-treated group-E decreased. Diabetic glomerular hypertrophy constitutes an early event in the progression of glomerular pathology which occurs in the absence of mesengial expansion (Malatiali et al., 2008). Although, the mechanism of renal hypertrophy is unknown, evidence suggest that local alterations in the production of one or more growth factors and/or their receptors are crucial to this process. Sharma \& Ziyadeh (1995) proposed that development of renal hypertrophy in insulin dependent diabetes mellitus (IDDM) was associated with overexpression of transforming growth factor (TGF) - beta 1 in the kidney especially in proximal convoluted tubules (PCT) cells and glomerular mesengial cells. Flyvbjerg et al. (1995) reported that renal hypertrophy, increased glomerular volume, mesengial proliferation and accumulation of glomerular extracellular matrix were due to growth hormone $(\mathrm{GH})$ and insulin like growth factors (IGFs) through a complex system consisting of growth hormone binding proteins (GHBP), insulin like growth factors (IGFS), insulin like growth factors receptors (IGF-receptors) insulin like growth factor binding proteins (IGFBP). Ahmed et al. (1998) attributed the renal hypertrophy and hyperplasia to increased epidermal growth factor (EGF). Liu et al. (1996) reported that diabetic renal hypertrophy might be due to HGF (hepatocyte growth factor) and c-met proto-oncogene product, a tyrosine kinase receptor for HGF. Possible mechanism for renal enlargement could be the direct effect of growth hormone (GF) and insulin like growth factor (IGF)-1 as reported by New et al. (1996) and Jacobs et al. (1997). Liu \& Barac-Nieto (1997) and Wu et al. (1997) investigated the mechanism of renal hypertrophy. They proposed that renal hypertrophy might be due to an increase in the rate of protein synthesis and/or decrease in the degradation of renal extracellular matrix components which occur early after induction of experimental diabetes before the onset of typical structural changes in the kidneys. Accelerated renal protein turnover and hypertrophy are early manifestations and perhaps harbingers of more severe renal changes in diabetes. All cell types in the glomerulus as well as proximal and distal tubule cells appear to be involved. Han et al. (1997) proposed that during diabetic renal hypertrophy, the cellular autophagy is inhibited in distal convoluted tubules (DCT) and proximal convoluted tubules (PCT) cells, suggesting that both type of cells contributed in a balanced manner to the hypertrophic growth of kidney cortex. Ichinose et al. (2006) proposed that increase in kidney weight is associated with the increase in renal expression of angiogenic factors such as vascular endothelial growth factor (VEGF) - A, angiopoietin (Ang) - 2 and fibrogenic factor transforming growth factor (TGF) - beta-1 induced by high glucose. Several other investigators (Habibuddin et al.; Lee et al.; Malatiali et al.) have reported increase in kidney weight per body weight in STZ-treated animals. Ren et al. reported marked enlargement of kidney weight/ body weight $(\mathrm{KW} / \mathrm{BW})$, tubulointerstitial fibrosis and fibronectin in streptozotocin-induced diabetic rats from 8 to 16 weeks. Activin betaA, mainly located in tubular epithelial cells, was significantly higher in diabetic groups than that in the non-diabetic groups. High glucose may facilitate the synthesis of activin betaA, transforming growth factor (TGF) -beta, P-Smad2/3 and fibronectin. They concluded that activin $A$ is involved in tubulointerstitial fibrosis in diabetes by inducing the production of fibronectin through Smad signal pathway.

In this study, the liver of treated animals were weighed in group-E and compared with the weight of liver of normal control animals in group-A. An increase (hypertrophy) in the weight of liver in proportion to the body weight was observed when the animals in group-E were compared with animals in group-A despite the fact that the mean weight of all the animals in treated group-E decreased. It could be attributed to increased triglyceride accumulation leading to enlarged liver which could be due to the increased influx of fatty acids into the liver induced by hypoinsulinemia and the low capacity of excretion of lipoprotein secretion from liver resulting from a deficiency of apolipoprotein B synthesis. Present finding of this study are in agreement with the findings of Habibuddin et al., Lee et al., Merzouk et al. (2000) and Ohno et al. (2000).

The observations on the weight of pancreas in relation to body weight in group-E and group-A animals did not show any change before and after STZ treatment. The body weight of animals and weight of pancreas decreased proportionately in group-E. The decrease in the weight of pancreas could be attributed to the disruption and disappearance of pancreatic islets and selective destruction of insulin-producing cells (Kim et al.; Heidari et al.).

It may be concluded that the streptozotocin through its direct alkylating action can cause cellular necrosis and selective destruction of the beta cells producing hyperglycaemia at a dose of $45 \mathrm{mg} / \mathrm{kg}$ body weight. It may also be stated that streptozotocin by producing diabetes (hyperglycaemia) and hypoinsulinemia causes reduction in the body weight of diabetic animals. It may also be concluded that the reduction in body weight was associated with increase in the relative weight of kidney and liver while the pancreas weight was unaffected. 
ZAFAR, M. \& NAEEM-UL-HASSAN NAQVI, S. Efectos de la diabetes inducida por STZ en los pesos relativos de riñón, hígado y páncreas en ratas albinas: un estudio comparativo. Int. J. Morphol., 28(1):127-133, 2010.

RESUMEN: Se estudiaron en ratas albinas los efectos de la diabetes inducida por estreptozotocina (STZ) sobre el peso corporal de los animales y los pesos relativos de riñón, hígado y páncreas. El objetivo del estudio fue encontrar una asociación entre la reducción del peso corporal de los animales diabéticos y los pesos relativos de riñón, hígado y páncreas en proporción al peso corporal de los animales. Este estudio fue realizado en el Departamento de Anatomía, Instituto de Ciencias Farmacéuticas, Universidad Médica Baqa y Departamento de Anatomía Patológica del Colegio de Médicos y Cirujanos Pakistán (CPSP) en 2007-08. La diabetes fue inducida por una dosis única de STZ (45 mg / kg de peso corporal) administrados por vía intraperitoneal en tampón de citrato de sodio a pH 4,5. Ochenta ratas Wistar se dividieron en cinco grupos: control (A) y STZ tratadas (B, C, D y E), que se sacrificaron 2, 4, 6 y 8 semanas después del tratamiento respectivamente. Todos los animales fueron pesados antes de la administración de estreptozotocina, y en el momento del sacrificio. El riñón, hígado y páncreas fueron removidos, secados y pesados sobre una balanza Sartorius. El peso corporal de los animales en los diferentes grupos cambió en intervalos de tiempo variables. El peso del riñón aumentó significativamente, el peso del hígado se incrementó ligeramente, mientras que el peso del páncreas no se modificó en comparación con el peso de los animales diabéticos. Parece que la diabetes inducida por STZ causa una reducción significativa del peso corporal de los animales diabéticos, mientras que el peso relativo de los riñones y elhígado se incrementaron y el peso de páncreas no se vio afectado.

PALABRAS ClAVE: STZ-diabetes; Peso corporal; Peso de riñones; Hígado; Páncreas; Ratas.

\section{REFERENCES}

Ahmed, I.; Adeghate, E.; Sharma, A. K.; Pallot, D. J. \& Singh, J. Effects of Momordica charantia fruit juice on islet morphology in the pancreas of the streptozotocindiabetic rat. Diabetes Res. Clin. Pract., 40(3):145-51, 1998.

Bennett, R. A. \& Pegg, A. E. Alkylation of DNA in rat tissues following administration of Streptozotocin. Can. Res., 41:2786-90, 1981.

Dorr, R. T. \& Fritz, W. L. Cancer chemotherapy. Hand book. London, Kinapton, 1980. pp.632-37.

Fadillioglu, E.; Kurcer, Z.; Parlakpinar, H.; Iraz, M. \& Gursul, C. Melatonin treatment against remote open injury induced by renal ischemia reperfusion injury in diabetes mellitus. Arch. Pharm. Res., 31(6):705-12, 2008 .

Flyvbjerg, A.; Landau, D.; Domene, H.; Hernandez, L.; Gronback, H. \& Le Roith, D. The role of growth hormone, insulin-like growth factors (IGFs), and IGF binding proteins in experimental diabetic kidney disease. Metabolism, 44(10):67-71, 1995.

Gu, D.; Arnush, M. \& Sarvetnic, N. Endocrine/exocrine intermediate cells in Streptozotocin treated Ins-IFNgamma transgenic mice. Pancreas, 15(3):246-50, 1997.

Habibuddin, M.; Daghriri, H. A.; Humaira, T.; Al-Qahtani, M. S. \& Hefzi, A. A. Antidiabetic effect of alcoholic extract of Caralluma sinaica L. on streptozotocin-induced diabetic rabbits. J. Ethnopharmacol., 117(2):215-20, 2008.

Han, K.; Zhou, H. \& Pfeifer, U. Inhibition and restimulation by insulin of cellular autophagy in distal tubular cells of the kidney in early diabetic rats. Kidney Blood Press. Res., 20(4):258-63, 1997.

Heidari, Z.; Mahmoudzadeh-Sagheb, H. \& Moudi, B. A quantitative study of sodium tungstate protective effect on pancreatic beta cells in streptozotocin-induced diabetic rats. Micron., 39(8):1300-5, 2008.

Ichinose, K.; Maeshima, Y.; Yamamoto, Y.; Kinomura, M.; Hirokoshi, K.; Kitayama, H.; Takazawa, Y.; Sugiyama, H.; Yamasaki, Y.; Agata, N. \& Makino, H. 2-(8-hydroxy6-methoxy-1-oxo-1h-2-benzopyran-3-yl) propionic acid, an inhibitor of angiogenesis, ameliorates renal alterations in obese type-2 diabetic mice. Diabetes, 55(5):1232-42, 2006.

Jacobs, M. L.; Chandrasekhar, V.; Bartke, A. \& Weber, R. F. Early effects of streptozotocin-induced diabetes on insulin-like growth factor-1 in the kidneys of growth hormone-transgenic and growth hormone-deficient dwarf mice. Exp. Nephrol., 5(4):337-44, 1997.

Kang, N.; Alexander, G.; Park, J. K.; Maasch, C.; Buchwalow, I.; Luft, L. C. \& Haller, H. Differential expression of protein kinase $\mathrm{C}$ isoforms in streptozotocin-induced diabetic rats. Kidney Int., 56(5):1737-50, 1999. 
Kim, J. D.; Kang, S. M.; Seo, B. I.; Choi, H. Y.; Choi, H. S. \& $\mathrm{Ku}, \mathrm{S}$. K. Anti-diabetic activity of SMK001, a poly herbal formula in streptozotocin-induced diabetic rats: therapeutic study. Biol. Pharm. Bull., 29(3):477-82, 2006.

Lee, S. I.; Kim, J. S.; Oh, S. H.; Park, K. Y.; Lee, H. G. \& Kim, S. D. Antihyperglycemic effect of Fomitopsis pinicola extracts in streptozotocin-induced diabetic rats. J. Med. Food, 11(3):518-24, 2008.

Liu, S. \& Barac-Nieto, M. Renal protein degradation in streptozotocin diabetic mice. Diabetes Res. Clin. Pract., 34(3):143-8, 1997.

Liu, Y.; Tolbert, E. M. \& Dworkin, L. D. In vivo and in vitro evidence for increased expression of HGF receptor in kidney of diabetic rat. Am. J. Physiol., 271(6 ):1202-10, 1996.

Magee, P. N. \& Swann, P. F. Nitroso compounds. Br. Med. Bull., 25:240-44, 1969.

Malatiali, S.; Francis, I. \& Barac-Nieto, M. Phlorizin prevents glomerular hyperfiltration but not hypertrophy in diabetic rats. Exp. Diabetes Res., 2008:305403, 2008.

Merzouk, H.; Madani, S.; Chabane, Sari, D.; Prost, J.; Bouchenak, M. \& Belleville, J. Time course of changes in serum glucose, insulin, lipids and tissue lipase activities in macrosomic offspring of rats with Streptozotocin induced diabetes. Clin. Sci. (Lond), 98(1):21-30, 2000.

Mozaffari, M. S.; Warren, B. K.; Russell, C. M. \& Schaffer, S. W. Renal function in the non-insulin dependent diabetic rat: effect of unilateral nephrectomy. $J$. Pharmacol. Toxicol, Methods, 37(4):197-203, 1997.

New, J. P.; Canavan, J. P.; Flyvbjerg, A.; Hamon, G.; Bilous, R. W. \& Marshall, S. M. Renal enlargement and insulinlike growth factor- 1 accumulation in the Wistar rat model of experimental diabetes is not prevented by Angiotensin converting enzyme inhibition. Diabetologia, 39(2):16671, 1996.

Ohno, T.; Horio, F.; Tanaka, S.; Terada, M.; Namikawa, T. \& Kitch, J. Fatty liver and hyperlipidemia in IDDM (insulin dependent diabetes mellitus) of Streptozotocin treated shrews. Life Sci., 66(2):125-31, 2000.

Oscika, T. M.; Yu, Y.; Panagiotopoulos, S.; Clavant, S. P.; Kirizis, Z.; Pike, R. N.; Pratt, L. M.; Russo, L. M.; Kemp, B. E.; Camper, W. D. \& Jerums, G. Prevention of albuminuria by aminoguanidine or ramipril in streptozotocin-induced diabetic rats is associated with the normalization of glomerular protein kinase C. Diabetes, 49(1):87-93, 2000.

Petlevski, R.; Hadzija, M.; Bajalo, J. L. \& Juretic, D. Effects of acarbose on alanine aminotransferase and aspartate aminotransferase activities in the liver of control and diabetic CBA mice. Acta. Pharm., 56(1):87-93, 2006.

Piyachaturawat, P.; Poprasit, J.; Glinsukon, T. \& Warichanon, C. Gastric mucosal lesions in Streptozotocin-diabetic rats. Cell. Biol. Intern. Rep., 12(1):53-63, 1988.

Piyachaturawat, P.; Poprasit, J. \& Glinsukon, T. Gastric mucosal secretions and lesions by different doses of Streptozotocin in rats. Toxicol. Lett., 55:21-29, 1991.

Punithavathi, V. R.; Anuthama, R. \& Prince, P. S. Combined treatment with naringin and vitamin $\mathrm{C}$ ameliorates streptozotocin-induced diabetes in male Wistar rats. $J$. Appl. Toxicol.; 28(6):806-13, 2008.

Ramesh, B. \& Pugalendi, K. V. Impact of umbelliferone (7hydroxycourmarin) on hepatic marker enzymes in Streptozotocin diabetic rats. Indian J. Pharmacol., 38:209-10, 2006.

Ren, X. J.; Guan, G. J.; Liu, G.; Zhang, T. \& Liu, G. H. Effect of activin A on tubulointerstitial fibrosis in diabetic nephropathy. Nephrology, 14(3):311-20, 2009.

Sharma, K. \& Ziyadeh, F. N. Hyperglycemia and diabetic kidney disease. The case for transforming growth factorbeta as a key mediator. Diabetes, 44(10):1139-46, 1995.

Swinscow, T. D. V. Statistics at square one. $7^{\text {th }}$ ed., London, Dawson and Good all, Ltd., 1981, pp 33-53.

Wu, K.; Setty, S.; Mauer, S. M.; Killen, P.; Nagase, H.; Michael, A. F. \& Tsilibary, E. C. Altered kidney matrix gene expression in early stages of experimental diabetes. Acta. Anat. (Basel), 158(3):155-65, 1997.

Zafar, M.; Naeem-ul-Hassan Naqvi, S.; Ahmed, M. \& Kaim Khani, Z. A. Altered liver morphology and enzymes in streptozotocin-induced diabetic rats. Int. J. Morphol., 27(3):719-25, 2009a.

Zafar, M.; Naeem-ul-Hassan Naqvi, S.; Ahmed, M. \& Kaim, Khani, Z. A. Altered kidney morphology and enzymes in streptozotocin-induced diabetic rats. Int. J. Morphol., 27(3):783-90, 2009b. 


\section{Correspondence to:}

Prof. Dr. Muhammad Zafar

Department of Anatomy, Faculty of Medicine

King Fahad Medical City, Riyadh, PO Box 50946, 11525

Saudi Arabia

Tel.:00966-1-2935238

00966-1-2889999 (ext.5981)

00966-561287496

Email: zafardoctor@hotmail.com mzafer@kfmc.med.sa

Received: 02-11-2009

Accepted: 14-12-2009 